\title{
Methodology and challenges of a complex multi-species eradication in the sub- Antarctic and immediate effects of invasive species removal
}

\author{
Keith Springer \\ Tasmania Parks and Wildlife Service, PO Box 126, Moonah, Tasmania 7009, Australia. \\ (Email: keith.springer@gmail.com) \\ Published online: 12 January 2016
}

\begin{abstract}
Vertebrate pest management on Macquarie Island has removed five vertebrate species since 1988; weka (Gallirallus australis scotti), cats (Felis catus), rabbits (Oryctolagus cuniculus), ship (black) rats (Rattus rattus) and house mice (Mus musculus). The latter three were eradicated in a combined eradication operation that commenced in 2006 and was declared successful in 2014. Eradication planning for removal of rabbits, rats and mice took about five years, with implementation another three years. The eradication comprised a two-phase project, with aerial baiting followed up by ground hunting using hunters and trained detection dogs to remove surviving rabbits. Rabbit Haemorrhagic Disease Virus was used as a non-target mitigation strategy prior to a second attempt at aerial baiting after adverse weather forced the abandonment of the first attempt. The project was considered complex, ambitious and challenging, partly because of the remote location with adverse weather conditions, but especially because multiple-species eradications are considered more difficult to achieve than single-species eradications. In addition, when eradication planning commenced Macquarie Island (12,785 ha) was many times larger than had previously been attempted for the removal of black rats and house mice (1000 and 800 ha, respectively). Preliminary empirical and anecdotal evidence is demonstrating the recovery of native flora and fauna in the absence of grazing and predatory mammals.
\end{abstract}

Keywords: Macquarie Island, eradication, Rattus rattus, Mus musculus, Oryctolagus cuniculus

\section{Introduction}

Macquarie Island is one of a small number of oceanic islands in the Southern Ocean (see Figure 1), and is of critical importance as a breeding ground for marine mammals and seabirds, due to the scarcity of alternate breeding sites. Part of the Australian state of Tasmania, it lies at $54^{\circ} 30^{\prime}$ 'South $158^{\circ} 57^{\prime}$ East and has an area of 12,785 ha. Discovered by sealers in July 1810 , fur seals (Arctocephalus sp.) were harvested to near-total decimation within 15 years. Elephant seals and penguins were harvested for oil from the 1870s until 1919 (Cumpston 1968; Jenkin et al. 1981). During this period several mammal species were introduced to the island and established feral populations. Rodents (mice and ship rats) came ashore accidentally, cats probably deliberately by 1815 , while rabbits and weka were introduced as a food source in the 1880s (Cumpston 1968). The Australian Antarctic Division (AAD) has maintained a research station on Macquarie Island since 1948.

\section{Vertebrate pest management}

Management of vertebrate pests on Macquarie Island has been undertaken since the late 1950 s, after concerns were raised by botanists about the destruction of native vegetation by high rabbit populations (Taylor 1955; Costin \& Moor 1960; Jenkin 1975). Varying methods of rabbit control (including poisoning trials) were undertaken through the $1950 \mathrm{~s}$ and $60 \mathrm{~s}$ but significant population control was not achieved until after the introduction of the myxoma virus in late 1978 (Brothers et al. 1982). An assessment of cat impacts in the early $1970 \mathrm{~s}$ estimated that feral cats were killing 60,000 burrowing seabirds annually, as well as preying upon rabbits and, to a much lesser extent, rodents (Jones 1977; Brothers et al. 1985). Cat control commenced in 1975 and continued with varying emphasis until a federal government-funded eradication project was implemented by the Tasmania Parks and Wildlife Service (Tas PWS) in 1998. This was successful in removing the last cat in 2000 (Robinson \& Copson 2014).

Although some researchers considered removal of cats to be the primary factor in an increasing rabbit population from the late 1990s (Bergstrom et al. 2009), this ignored the rabbit population cycles that had occurred since early studies in the 1950 s and probably prior to that when they were unstudied; and also discounted the fact that rabbit numbers were considered to be higher in the mid 1970s when cat and rabbit populations were uncontrolled. By postulating that cat predation was the primary limiting factor on rabbit numbers, Bergstrom et al. (2009) ignored previous documented serious overgrazing of vegetation in the 1940s and 50s due to high rabbit numbers (Law \& Burstall 1956). They did not present an argument that explained how rabbits managed to establish initially in the face of cat predation, when cats had already been present on the island for over 60 years and thus could obviously sustain a viable population in the absence of rabbits, nor how the mid-1970s rabbit population peak (that was as least as high as the 2000 s population) could occur when there was then no cat control undertaken. This suggests that other factors may have had a greater influence in limiting rabbit numbers. By the early 2000s, the myxoma virus that had been used for rabbit control for over 20 years was no longer available and the rabbit population was showing resistance to the virus (i.e. blood samples tested positive for antibodies), suggesting that release from a biological control agent and a burgeoning food supply after 20 years of vegetation regrowth (as a result of effective rabbit control) were more causative factors in rabbit increases (Dowding et al. 2009; Terauds et al. 2014), which peaked in 2006 (Terauds 2009). The reasons for further vertebrate pest management lay in addressing the significant impacts of the remaining pest species; primarily those related to predation 
$150^{\circ} \mathrm{E}$

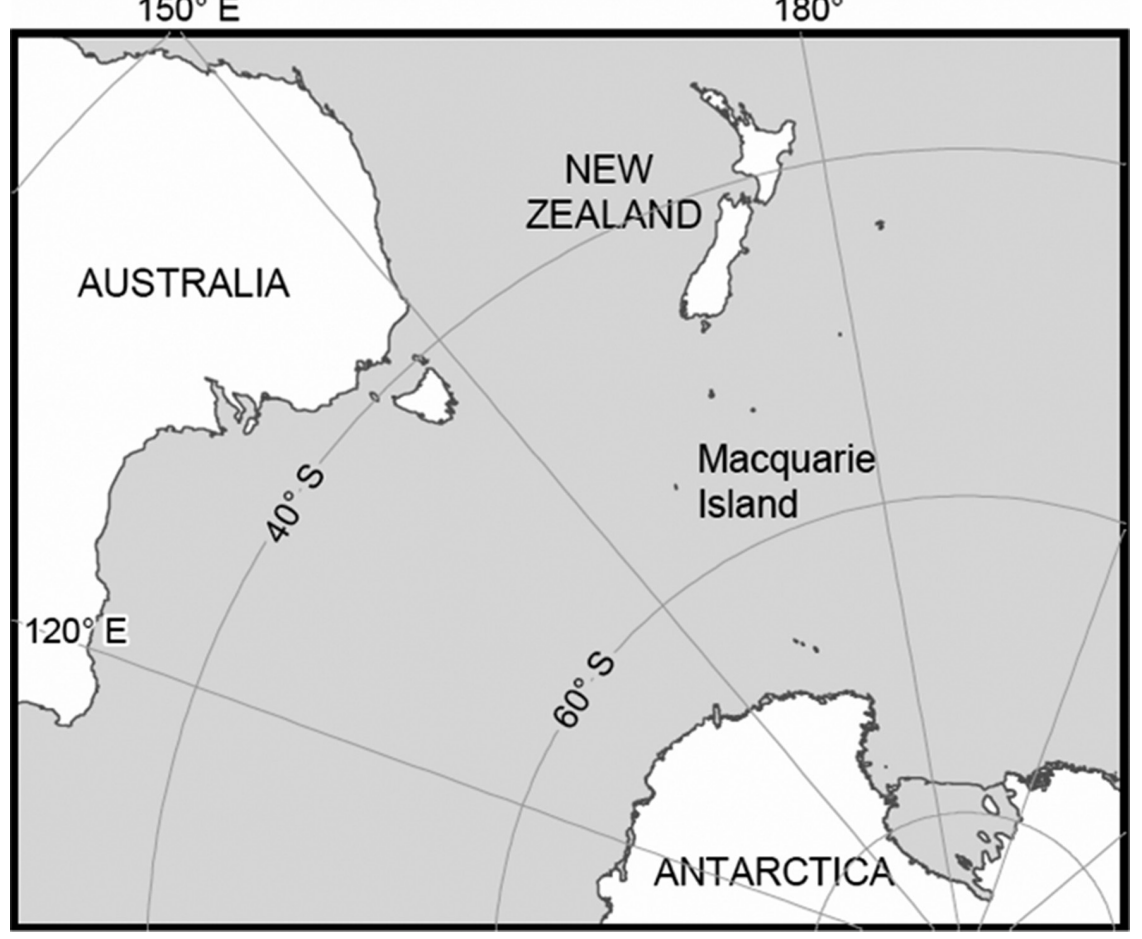

Figure 1. Macquarie Island lies in the Southern Ocean about halfway between New Zealand and Antarctica. Long and narrow, it is the exposed crest of an oceanic ridge on the continental plate boundary. on burrowing seabirds (rats) and invertebrates (rats and mice) and impacts on vegetation communities (rats and rabbits) (Tasmania Parks and Wildlife Service 2007).

\section{Eradication of rabbits and rodents}

From 2000, advances in technology and methodology were enabling the eradication of rodents and rabbits from islands, especially around New Zealand, and larger and more ambitious islands were being considered as achievable (Howald et al. 2007). The successful eradication of Norway rats (Rattus norvegicus) from Campbell Island in 2001 was a significant precedent that demonstrated the capacity to remove rodents from islands hitherto considered too large and remote to be possible, and demonstrated other key lessons that could be applied to islands such as Macquarie. In the case of Macquarie Island, a campaign to remove the remaining vertebrate pests should be a simultaneous operation because they were all susceptible to the same methodology, thus it was more cost effective and operationally efficient to target three pest species simultaneously.

Encouraged by the success on Campbell, Tas PWS commenced planning in late 2004 for a multiple-species eradication on Macquarie, and in a 12-month period developed an operational plan. This period was notable for a shift in management outlook from a position where biological control of rabbits was the primary vertebrate pest control method and no feasible rodent control was undertaken, to a position where the total eradication of three pest species was the management focus. The strategy developed for both rodent and rabbit eradications relied heavily on the lessons, experience and outcomes of previous island eradication projects targeting these species.

Further planning commenced in October 2006 and joint funding of $\$ 24.7 \mathrm{M}$ from the Tasmanian and Commonwealth governments was committed in June 2007 to implement the project, with an operational commencement scheduled for the winter of 2010. Planning was based on an aerial application of Pestoff 20R-a rodenticide bait containing brodifacoum at 20 parts per million (Animal Control Products, Wanganui, NZ). This method was designed to eradicate both rodent species and $>99 \%$ of rabbits, and a follow up period of three years was planned to remove surviving rabbits using hunters with trained detection dogs, traps, firearms and burrow fumigants. A further two year monitoring period was scheduled before eradication would be deemed successful.

Planning was complex and centred on four aspectsregulatory, logistics, strategic and staffing. This included approximately 30 permits and approvals required to implement the project and writing 10 component plans comprising the overall eradication plan. Logistics planning included the procurement of helicopters, experienced baiting pilots, baiting equipment, 305 tonnes of bait, ships, dogs, field equipment, huts and recruitment of about 60 staff through the duration of the project.

\section{Operational phase_-aerial baiting 2010}

Departure from Hobart, Tasmania was scheduled for late April 2010, however the unavailability of the selected vessel $(R V$ Aurora Australis, P\&O) due to a 20 -year survey at precisely that time meant that departure was delayed until May $22^{\text {nd }}$. On arrival at Macquarie Island ( $25^{\text {th }}$ May) the ship was unloaded and bait depots established at Hurd Point (south-east corner of the island), Green Gorge (midway up the east coast) and The Isthmus (at the northern end of the island), where the team were accommodated at the AAD research station. Baiting commenced on June $2^{\text {nd }}$ but persistent low cloud and high winds meant very little progress was achieved, and in a three week period from late June to mid July the helicopters were unable to get airborne at all due to bad weather. On about July $20^{\text {th }}$ the decision was made to abandon operations after baiting about $8 \%$ of the island, as the likelihood of sufficient good weather in the remaining few weeks before the return of wildlife in 
the spring was low; and persisting would have increased the impact on non-target species, with no guarantee of getting the baiting completed within the permitted timeframe by the start of September. Before departure five temporary field huts were placed around the island to support rabbit hunting teams. The team returned to Hobart in early August 2010, and commenced provisional planning for a return to the island in the winter of 2011. A review was commissioned by the federal Department of Environment due to concerns about the extent of non-target mortality (although this had been foreshadowed in the project Environmental Impact Statement), and found that the impacts of doing nothing (i.e. abandoning the project) on the island ecosystem were greater than the likely non-target mortality that could be expected from continuing.

\section{Operational phase-RHDV use and aerial baiting 2011}

Separate to the formal review, and acting on advice received from the Island Eradication Advisory Group (NZ Department of Conservation), Rabbit Haemorrhagic Disease Virus (RHDV) was released on Macquarie Island in February 2011, prior to the arrival of the aerial baiting team and about two and a half months before the first bait drop. This was a strategy to reduce the extent of non-target mortality amongst scavenging seabird species - primarily skua and giant petrels. Timing of the virus release was carefully considered to ensure rabbit carcasses were eliminated through scavenging and decay well before poisoned baits would appear, but was late enough so that vegetation regrowth (from reduced rabbit numbers) would not provide a significant natural alternate food source for rabbits when baiting commenced. Two hundred kilograms of carrots were manually grated and used at 10 selected sites (based on high rabbit densities) both as pre-feed and to distribute the virus. Rabbit mortality on a massive scale was evident within a day or two at release sites and spread rapidly through the population, reducing it by an estimated $80-90 \%$ (Springer \& Carmichael 2012).

An order of 239 tonnes of bait was placed to supplement that left on the island from the previous winter. While staff had checked the condition of the bait within bait pods left on the island up until early January 2011 and reported it dry, there was still a risk of weather egress and spoilt bait in the 5-6 months until the bait would be spread. In the event, nearly all of the year-old bait was still in good condition on the bait pods being opened, giving confidence in this storage method when left in the elements, and the shelf life of the product. Due to the precautionary provision of fresh bait however, most of the earlier consignment was not used, except for the third (limited area) bait drop and as a contingency supply.

Existing contracts for bait, shipping and helicopters were renegotiated with the previous suppliers.

The voyage transporting the aerial baiting team departed Hobart in late April 2011 and completed the depot-laying at the same sites as 2010 before the end of April. Twelve rabbitdetection dogs owned by Tas PWS and trained under contract to department specifications were also taken to the island on this voyage. Suitable weather conditions during early May saw the first bait drop completed by May $19^{\text {th }}$, and with sufficient good weather in June the second bait drop was completed by June $20^{\text {th }}$. A third bait drop was done in areas that were identified as having had high rabbit densities, or that provided particularly attractive rat habitat, such as around penguin colonies. This drop was completed by July $12^{\text {th }}$. In addition, all off-shore rock stacks were baited with a trickle bucket, whether rats were known to be on them or not; and on-shore stacks were given an additional treatment due to the abundance of nesting and burrowing habitat for both rodents and rabbits. A small area that was too steep and rugged to allow safe foot access for follow-up hunting was also treated with Pindone carrots, to offer rabbits an alternate bait source to Pestoff $20 \mathrm{R}$ cereal baits. At the end of July a ship delivered the rabbit hunting team and picked up the aerial baiting team.

The aerial baiting phase used two AS350BA and two AS350B2 helicopters provided by Helicopter Resources (Hobart, Tasmania) along with two engineers; while pilots, baiting buckets, GPS units (Tracmap, Otago, NZ) and switching gear were provided by Central South Island Helicopters (Herbert, NZ) along with two ground staff to look after the buckets, GPS units and switching equipment. Three bait depots were established and each was laid out in two parallel lines (435 bait pods in total, each containing $700 \mathrm{~kg}$ of bait). A loading team of five was responsible for loading bait for helicopters on each line-two people tipping bait bags into the bucket, two receiving and securing empty bait bags, and a team leader guiding the bucket into place and supervising the site. An additional bait loader rotated between teams to allow individuals a break from the loading, which was occurring at the rate of a load about every 10-15 minutes. Loads consisted of $500 \mathrm{~kg}$ of bait for the BA Squirrels $(20 \times 25 \mathrm{~kg}$ bags) and $650 \mathrm{~kg}$ of bait for the B2 Squirrels (26 x $25 \mathrm{~kg}$ bags), with the BAs working on the plateau bait lines where the application rate was lower $(24 \mathrm{~kg} / \mathrm{ha})$ and the B2s working on the escarpment slopes $(36 \mathrm{~kg} / \mathrm{ha})$ and coastal areas $(44 \mathrm{~kg} / \mathrm{ha})$ where the rate was higher. Bait was loaded into buckets from the top of the bait pods with rubber matting to provide a non-slip work surface. The buckets were landed onto a sheet of fibreglass reinforced plastic (FRP) adjacent to the loading platform, with the FRP providing a flat stable surface (smooth side up so the bucket can be more easily slid into position). The on-site team included the project manager coordinating the allocation of aircraft to flight lines, a GIS technical person to download flight line data and provide flight following, and a baiting advisor/safety officer who had an oversight role around the load site. One of the helicopter ground crew was also at the loading site to refuel helicopters and bucket motors. A separate team of four formed a non-target mitigation team, tasked with patrolling the island to locate and bury carcasses of target and non-target animals to remove them from scavengers, a role supplemented by other team members when available. As a strategy to reduce non-target mortality the efficacy of this was considered limited, as the majority of carcasses located were already scavenged (Springer \& Carmichael 2012). In terms of outcomes, the release of RHDV was far more successful in limiting impacts on scavenging seabirds. After limited baiting in 2010 ( $8 \%$ of island baited once) a total of 960 carcasses were recovered (approximately 0.93 per hectare of island) whereas following more intensive searching after $100 \%$ of the island was baited twice in 2011, a total of 1,464 carcases were recovered, a rate of 0.11 carcases per hectare of island.

\section{Operational phase — rabbit hunting and monitoring 2011- 2014}

The operational strategy was based on previous rabbit eradication projects suggesting not every rabbit would find the bait palatable and that a very small number of survivors should be anticipated (Broome \& Brown 2010). Survivors could be expected to be mobile in search of mates and given 
the known fecundity of rabbits the population could begin to increase immediately. Therefore it was critical to put maximum hunting pressure on survivors as soon as poison baiting was complete. This would inhibit the incidence of breeding and prevent the rate of increase exceeding the rate survivors were located and killed. Even a $0.1 \%$ survivorship from an initial population estimated at around 150,000 (in winter) (Terauds 2009) suggested that well over a hundred rabbits could survive aerial baiting. Hunting operations commenced in August 2011.

For the hunting phase, the island was divided into six blocks. Each block had two huts available to base operations from. Two staff were allocated to each hunting blockincluding a dog handler with two dogs - on a roster which rotated clockwise every two weeks. For the first seven months, an additional two staff were employed to provide a flexible response to any areas where additional hunting pressure was needed. This team also provided an additional spotlighting resource. The initial strategy was to cover as much ground in each block as possible in a systematic fashion, looking for any sign of rabbits and then applying a strategy to remove individuals as found. This strategy resulted in eight adult rabbits being located and killed, in addition to one adult found and removed prior to the completion of the baiting phase. A single litter of four recently-weaned kits was found in November 2011. These were the last rabbits killed in the hunting phase and brought the total number killed to 13 , of which eight were considered adult survivors (two female) of the aerial baiting and preceding RHDV campaigns. Evidence of at least three further rabbits was established but these individuals were never located and were assumed to have died from other causes. This total was well below expectations and indicated that the combination of RHDV and baiting had removed nearly the entire rabbit population. Dogs proved instrumental in detecting most of the located rabbits, and trapping was a successfully used technique. Spotlighting was emphasised as a critical hunting method throughout the project due to the ability to detect rabbits at a distance via eyeshine, and the nocturnal habits of rabbits meaning they were often active at night.

The hunting team was replaced in April 2012 with a 13-strong team and again in April 2013 with a nine person team (two fewer than planned due to staff issues). An additional two staff with three rodent detection dogs deployed to the island in April 2013 and both stayed for 12 months setting out rodent monitoring equipment (chew sticks, wax tags and tracking tunnels) and searching the island for rodent sign with dogs. Each member of the hunting team carried a GPS and logged all field travel. Search effort by dogs was many times that of their handlers by area covered, but was not logged. The GPS data was downloaded fortnightly by the team leader and the cumulative data tracked progress and identified any gaps that needed to be covered. Team meetings were held monthly and cumulative search coverage displayed on screen, providing a visual representation of progress that enhanced motivation and focused attention on areas missed or the next areas to be covered.

The field work from April 2012 was considered monitoring work (shortening the planned three-year hunting period to seven months), and continued for the prescribed two-year period, concluding in March 2014, at which time the field teams, dogs and most equipment were removed from the island. The monitoring work was considered critical because the island is so large and terrain so complex that intensive searching over an extended time period needed to be undertaken to gain confidence that no pest individuals remained.

\section{Assessing eradication success}

Assessment of eradication success was based on the amount of search effort that had been applied in the period since hunting began, compared with sign found over that time period. The extent of search coverage from GPS tracks was also assessed, with the acknowledgement that the same search techniques had been successful in detecting rabbits in the months after aerial baiting concluded, so were proven detection methods if rabbits were present. The logged distance of search effort from August 2011 to March 2014 was over 92,000 km, and included about two complete sweeps of the island each year. Rodent monitoring was critical, as low discrete surviving populations could be extremely difficult to detect. With the declaration of eradication success, Macquarie Island became the largest island in the world to date from which ship rats, house mice and rabbits had been removed.

\section{Monitoring recovery}

Efforts to systemically study the ecological changes resulting from removal of introduced mammals have been hampered by a lack of funding, however in the 2012/13 and 2013/14 summers botanists were able to spend time on the island measuring long-term vegetation study sites that demonstrated a substantial recovery in native vegetation extent and biodiversity. Vegetation recovery has been well documented by comparing photo monitoring sites from before and after rabbit eradication (see Figures $2 \mathrm{a}$ and $2 \mathrm{~b}$ ), and the regrowth of vegetation outside rabbit exclosure plots. Significant recovery across favourable sites has been recorded for the dominant species Poa foliosa, Stilbocarpus polaris and Pleurophyllum hookeri, while the prickly shield fern Polystichum vestitum is also showing signs of regrowth. The formerly site-restricted tussock Poa litorosa is now found in a wider distribution, and numerous grassland and smaller herbfield plants are demonstrating significant recovery.

Monitoring of burrowing and surface nesting petrels likewise demonstrated that some species were again breeding on the main island, some colonising from rat-free offshore rock stacks. Notable breeding activity and increased breeding success has been recorded or observed for soft-plumaged petrel, blue petrel, grey petrel, Cape petrel and diving petrel; while Antarctic tern breeding behaviour has shown a marked change in location from rock-stacks to cobblestone beach areas. Species impacted by the baiting such as northern giant petrels and kelp gulls (Springer \& Carmichael 2012) are also showing signs of recovery with the exception of skua. These were expected to reach a lower population equilibrium than previously, given the removal of one of their key prey species - the rabbit; which had supported a skua population on the plateau that was unlikely to be sustainable in the absence of rabbits.

Anecdotal evidence has shown significant increases in spider and moth populations amongst the invertebrate community, and this aspect will be further studied.

Anumber of monitoring study results have been published in the Tas PWS Evaluated Case Study: Macquarie Island Pest Eradication Project (Jones \& Springer 2014).

\section{Biosecurity}

Stringent biosecurity measures are the primary means of safeguarding the investment made in eradicating vertebrate pests from islands. Planning for improved biosecurity policy and procedures for Macquarie Island began in 2007 with a multi-agency group, recognising that although PWS (a state 

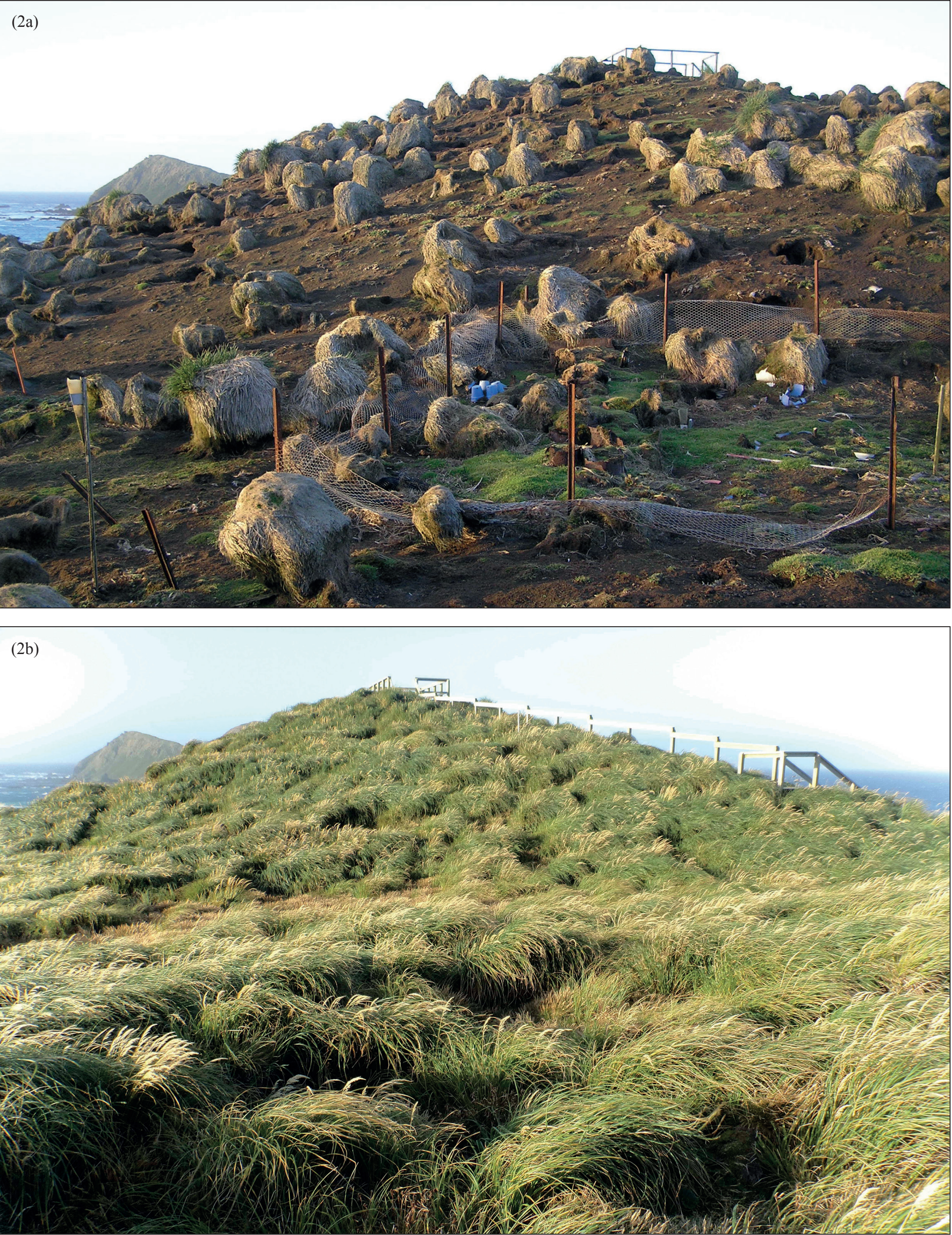

Figure 2. Razorback Spur at the base of The Isthmus on Macquarie Island, 54³0’17.92”S, 158 55'50.91'E. Photos taken April 2005 (2a) prior to and March 2014 (2b) since the removal of invasive rabbits illustrate the scale of vegetation recovery underway in the absence of grazing animals. Photos by Keith Springer. 
government agency) has management responsibility for the island; all logistics for the island is managed by the (federal government) $\mathrm{AAD}$, who operate the research station and undertake all cargo, resupply and staff changeover operations. The goal in the early stages was to have enhanced biosecurity measures embedded before the eradication operation started so that improved measures (and mindsets) were standard before field operations commenced. Biosecurity planning was a management measure for the island in wider terms than just vertebrate pests and so was managed outside the core eradication project team, and in liaison with the AAD. In the event, policy and procedures were slow to change and it was not until after aerial baiting was concluded that significantly improved facilities and procedures were introduced in 2013. The discovery of mouse droppings within cargo delivered to the island after the baiting underscored the importance of improved cargo scrutiny, but while procedures and facilities have improved significantly a jointly agreed biosecurity plan is still to be finalised. Improved biosecurity measures in Hobart did detect and remove a mouse from within the cargo biosecurity zone in 2014 just prior to a Macquarie Island resupply, demonstrating the need for and value of improved procedures and mindset.

\section{Conclusion}

The removal of rabbits, ship rats and especially house mice from Macquarie Island was seen as an ambitious and challenging project. That it succeeded despite many challenges is a significant milestone in global island eradications and will hopefully encourage similar measures on other islands where pests are causing significant impacts to native flora and fauna. Crucially, biosecurity measures need to be robust and maintained at a high level in perpetuity if conservation and biodiversity gains are to be realised long term. Project objectives of recovery of vegetation, seabirds and invertebrates are beginning to be realised. The project cost was below budget (approximate cost $\mathrm{A} \$ 20 \mathrm{M}$ vs. budgeted $\mathrm{A} \$ 24.7 \mathrm{M}$ ) and despite the delay of a year with the repeat of the aerial baiting phase, was completed a year ahead of schedule.

\section{Acknowledgements}

Thank you to the organisers of the $50^{\text {th }}$ Anniversary of Rodent Eradications in New Zealand symposium and invitation to present this paper. Earlier drafts of this article were improved following reviews by Keith Broome and James Russell and two anonymous reviewers.

\section{References}

Bergstrom DM, Lucieer A, Kiefer K, Wasley J, Belbin L, Pederson TK, Chown SL 2009. Indirect effects of invasive species removal devastate world heritage island. Journal of Applied Ecology 46: 73-81.

Broome KG, Brown D 2010. Current agreed best practice for rabbit eradication on islands. In: Murphy E, Crowell $\mathrm{M}$, Henderson $\mathrm{W}$ eds Workshop proceedings: improving the efficiency of rabbit eradications on islands 4-5 February 2010, Christchurch. Canberra, Invasive Animals
Cooperative Research Centre. Pp. 74-93.

Brothers NP, Eberhard IE, Copson GR, Skira IJ 1982. Control of rabbits Oryctolagus cuniculus on Macquarie Island by myxomatosis. Australian Wildlife Research 9: 477-485.

Brothers NP, Skira IJ, Copson GR 1985. Biology of the feral cat, Felis catus (L.) on Macquarie Island. Australian Wildlife Research 12: 425-436.

Costin AB, Moore DM 1960. The effects of rabbit grazing on the grasslands of Macquarie Island. Journal of Ecology 48: 729-732.

Cumpston JS 1968. Macquarie Island. ANARE Scientific Reports, Series A (1). ANARE publication No.93. Melbourne, Antarctic Division, Department of External Affairs. 380 p.

Dowding JE, Murphy EC, Springer K, Peacock AJ, Krebs CJ 2009. Cats, rabbits, Myxoma virus, and vegetation on Macquarie Island: a comment on Bergstrom et al. (2009). Journal of Applied Ecology 46: 1129-1132.

Howald G, Donlan CJ, Galvan JB, Russell JC, Parkes J, Samaniego A, Wang Y, Veitch D, Genovesi P, Pascal M, Saunders A, Tershy B 2007. Invasive rodent eradications on islands. Conservation Biology 21: 1258-1268.

Jenkin JF 1975. Macquarie Island, Subantarctic. In: Rowewell T, Heal OW eds Structure and function of tundra ecosystems. Stockholm, Swedish Natural Science Research Council. Ecological Bulletin 20: 375-397.

Jenkin JF, Johnstone GW, Copson GR 1981. Introduced animal and plant species on Macquarie Island. Colloque sur les ecosystems subantarctics, Paimpont, CNFRA 51: 301-313.

Jones E 1977. Ecology of the feral cat Felis catus (L.), (Carnivorus Felidae) on Macquarie Island. Australian Wildlife Research 4: 249-262.

Jones G, Springer K 2014. Evaluation report: Macquarie Island pest eradication project. Hobart, Tasmania, Parks and Wildlife Service (Department of Primary Industries, Parks, Water and Environment). 50 p.

Law PG, Burstall T 1956. Macquarie Island. ANARE Interim Report No. 14. ANARE Publication No. 29. 48 p.

Robinson SA, Copson GR 2014. Eradication of cats (Felis catus) from sub-Antarctic Macquarie Island. Ecological Management \& Restoration 15: 34-40.

Springer K, Carmichael N 2012. Non-target species management for the Macquarie Island pest eradication project. Proceedings of the $25^{\text {th }}$ Vertebrate Pest Conference. Davis, California, University of California. Pp. 38-47.

Tasmania Parks and Wildlife Service 2007. Macquarie Island pest eradication plan. Part A - overview. Hobart, Department of Environment, Water, Heritage and the Arts. 53 p.

Taylor BW 1955. The flora, vegetation and soils of Macquarie Island. ANARE Reports Series B (2) no. 19. Melbourne, Antarctic Division, Department of External Affairs. 192 p.

Terauds A 2009. Changes in rabbit numbers on Macquarie Island 1974-2008. Report for the Tasmania Parks and Wildlife Service (unpublished).

Terauds A, Doube J, McKinlay J, Springer K 2014. Using long-term population trends of an invasive herbivore to quantify the impact of management actions in the subAntarctic. Polar Biology 37: 833-843. 